\title{
A STUDY TO TEST STOCK RETURN BASED ON PE STRATEGY AND THE COMBINATION BETWEEN PE AND 200 DMA STRATEGY IN COMPARISON TO THE RETURN GENERATED BY BUY AND HOLD STRATEGY
}

\author{
Anthony Alvin ${ }^{1}$ \\ BINUS University International, Jakarta \\ Dian Triasurya ${ }^{2}$ \\ BINUS University International, Jakarta
}

\begin{abstract}
The main purpose of this study is to test a market perception that a low Price to Earnings ratio (PE) relatives to 5-year historical average and the combination with 200 Daily Moving Average (DMA), are a good indicator to generate buy \& sell signal that can beat buy \& hold strategy.

The research uses 28 samples taken from 45 companies in the Kompas 100 index. The first study will use low PE, when company's PE is below its 5-years average PE, the buy signal will be generated. The second study will use combination of low PE and 200 DMA, if PE of company below its 5-years average and its stock price is above 200 DMA, the buy signal will be generated. The T-test analysis will be conducted whether the different return between PE and PEDMA with buy and hold strategy is significant or not.

The results shows that the low PE strategy and the combination of PE and DMA can give positive returns to the investor although it cannot beat the return by using buy \& hold strategy. The investor cannot only use low PE as a single indicator in buying or selling stock, there should be another parameters.
\end{abstract}

Keywords: Price to Earnings Ratio (PE), 200 Daily Moving Average (DMA), Stock prices.

\footnotetext{
${ }^{1,2}$ Anthony Alvin is an alumni of BINUS University International (ask_why_25@yahoo.com). Dian Triasurya is a faculty of BINUS University International (dtriasurya@binus.edu).
} 


\section{BACKGROUND}

There are some ways to invest money which are investing in business, investing in real estates, saving in the bank and investing in capital market. Investing in capital market especially stocks market has become more popular in this age because it offers an interesting return if it is invested correctly. However, it is not a gamble because unlike gambling that is based on pure luck, in investing people can weigh their decision by analyzing the companies' financial data, the industry condition, price movement, inflation, etc. By doing so, investors could decide whether the price of the stock is worth to buy or not.

Seyhun (2000) found that the PE ratio expresses the relationship between stock prices and the earning per share. Most investors use PE ratio as an indicator of buying or selling decisions. The companies with high growth ratio will have high growth $\mathrm{PE}$ ratio. The high growth rate looks attractive for investors, but it can be tricky.

According to Basu (1977), PE ratios are the predictors of future performance. For investors, it is better to buy stock which has Low PE ratio. The companies with high $\mathrm{PE}$ ratio can be considered as the overpriced stock. There are some reasons behind it such as a bull market, news about the company, and the industry. On the other hand, Low PE stocks can be considered that the stock is under priced than the actual price.

The price earnings ratio is the fundamental analysis that is used to find out whether the market price is overvalued or undervalued comparing to the value of the company. The author decides to use technical analysis also to help investor make a decision. The investor can know the trend of the stock by looking of moving averages. The author decides to use 200 moving averages becasue the longer period of MA can smooth out the price movement which can confuse the investors. The low PE ratio could be used to select the undervalued however, it is unless there is good buying interest, and cheap stocks can remain cheap for quite long time. Here 200 days moving average will come in handy to helps us to select stocks with the tendency of resuming buying interest.

Investors must analyze the company thoroughly, to know whether the company is fundamentally sound good and whether the stock price represents any value to buy at the moment, before buying the stock. This 
could be done by fundamental analysis. However, the price of the stock could go up just because there are the other people who want to pay more for that stock. Technical analysis could help investor to time the entry or exit point.

The data used in this study are the companies from Kompas 100 from the first trading at January 2005 to December 2009 .The time horizon is 5 years. The author benchmark to the 28 companies instead of 100 companies because the rest were go public after 2000 and some data of the companies are not available.

This study aims to test whether low PE Ratio can help investors making buy or sell decisions yielding above Buy and Hold returns and to test whether the combination between low PE ratio and above 200 DMA can give returns yielding above Buy and Hold strategy.

\section{Research Hypothesis}

H1: There is a significance difference in return between PE and Buy and Hold strategy

H2: There is a significance difference in return between PEDMA and Buy and Hold strategy

\section{THEORITICAL FOUNDATION}

$\mathrm{PE}$ ratio is the most well known ratio that is used by investor to value the stock. The PE ratio is calculated by dividing the market price by earning per share of the company. Brigham E. F., (1993) stated that the PE ratio does not give us a full information by itself, it should be compared to the $\mathrm{PE}$ ratio to the other company in the same industry, to the market, and the company's historical PE. The author want to explore more how the investor uses PE ratio comparing to the company historical PE.

There is a study done by Benjamin Graham (1934), called value investing. This approach is to buy stocks which is lower than their intrinsic value. Value investing is an approach to find stocks that are selling at a discount prices or the market value is below the intrinsic value. The problem is how do investor know the whether the stocks is sold below the intrinsic value. 


\section{Factors affecting stock market}

According to Smith (2008), there are some factors that can affect and drive the stock prices:

1. Market condition

Usually in a bull market, the price of most companies will rise, on the other hand, in a bear market, most company stock prices will go down.

2. The industry condition

The stock price of the company could go along to the other company's stock prices in same industry. However, there is an exception for some cases, for example, the company will get a benefit if there is bad news related to their competitors.

3. The earning results

The earning of the company reflects the condition of the company. If the earning reports good earnings, it could create a buying momentum of the company stock in the market.

5. Investment gurus

Usually the decision of the investment gurus can also drives the stock prices.

6. Insider trading

If the insider decides to buy or sell their shares, it means there could be a good or bad news about the company.

7. Buy-back

If the company decides to buy back shares in the market, it means that the amount of the shares available in the market will decrease. Based on the law of demand and supply, if the supply of the stock is decreasing, the price will go up.

8. Interest rates

If the interest rates is high, many people tend to put their money in the bank instead investing in the stock market. It could cause a bear market as price of the stocks could decline.

9. Demand \& Supply

If there is a tendency of buying trend or increasing demand for the stock, the price of the stock will go up. On the other hand, the stock will go down if there is a selling trend tendency or increasing supply for the stock (Malhotra, 2007) 


\section{Price earning ratio}

Price earning ratio is firstly introduced as an indicator of company valuation by Graham and Dod in 1934. Now it becomes the most well known ratio for investors to make a valuation according to Loth (1999). The PE ratio is measured by dividing the price per share by earning per share.

"The price-earnings ratio is part of the everyday vocabulary of investors in the stock market," said Brealey and Myers in Principles of Corporate Finance. Brealey (1996) found that the high PE ratio reflects the investor thought that the firm had good growth opportunitites that make the earnings are relatively safe. Furthermore, Thomas (1994) said in Indianapolis Business Journal, "while accepting that a high PE ratio is usually a sign of high expectations, analysts and brokers nonetheless are quick to caution that the ratios are only part of the puzzle"

The study done by Basu (1977) from 1957 until 1971 shows that the company with low PE ratio gave higher returns compare to the company with high PE ratio. This study contradict with efficient market hypothesis that the price does not impound the information immediately. The study done by Campbell and Schiller (1988) also strengthen the theory by founding that PE ratios have a great prediction power. Furthermore, Jaffe.et.al (1989) also support that the market is not efficient so the existence of PE ratio can be an useful tool to predict the stock returns, they added the evidence that the low PE ratio can give higher returns.

\section{How people use it}

According to Bennet (2007), PE ratio cannot tell anything, it should be compared to the other company in the same industry and the historical PE of the company itself. Thus, the investors can make a decision based on the comparison.

There was a study before by Nicholson (1960) analyzing 100 stocks from different industries from 1939 to 1959 and the result was that company with low PE ratio give investors 14.7 times their investment compare to the company with high PE ratio that just give 4.7 times their investment. Based on his study, he concluded that the purchaser of common stocks may logically seek the greater productivity represented by stocks with low rather than high price earnings ratios. 
A research that conducted by Fama and French (1992) that used stocks from NYSE, NASDAQ, Amerian Stock Exchange from July 1965 until December 1990, concluded that the stock with low PE ratio tends to outperform the stock with high PE ratio. Another study done by Truong (2009) in New Zealand from 1997 to 2007 also supports the idea that low $\mathrm{PE}$ ratio is outperform the high $\mathrm{PE}$ ratio. She used companies from different industries which their stocks are traded in New Zealand Stock Exchange.

\section{Why we use 5 years Price earning ratio}

The author decides to use 5years PE ratio because the earning in the recent years sometimes does not reflect the true earning power (Beddard, 2009). For example, If you buy a stock based on the particularly good year, you might not get your expected results. Further more, Campbell et al (1988) find that there is too much noise if the investors are just looking for one year interval, but the noise tends to cancel out over the longer time intervals.

\section{Moving averages}

If the fundamental analysis is used to find the undervalue stock, the technical analysis is used to determine the trend of the stock. One of the best technical analyses that are commonly used by the investors is the moving average. 200 days moving average is the most popular among the investors. 200 days moving average is the average of the closing price of the stock over past 200 days. The 200 days moving average can help investors to know the market trend whether it is upward or downward.

When the price is above 200 days moving average, it can be intepreted that the trend is upward, hence, the investors should consider to buy the stock. On the other hand if the price is below 200 days moving average, it gives a signal to the investor that the trend is downward, hence, the investors should consider to sell the stocks to avoid losses (200dma, 2006).

A research by Connors from 1989 to 2006 which use S\&P500 and NASDAQ stocks have shown that the price above 200 DMA tends to outperform the a stock with below 200 DMA. 


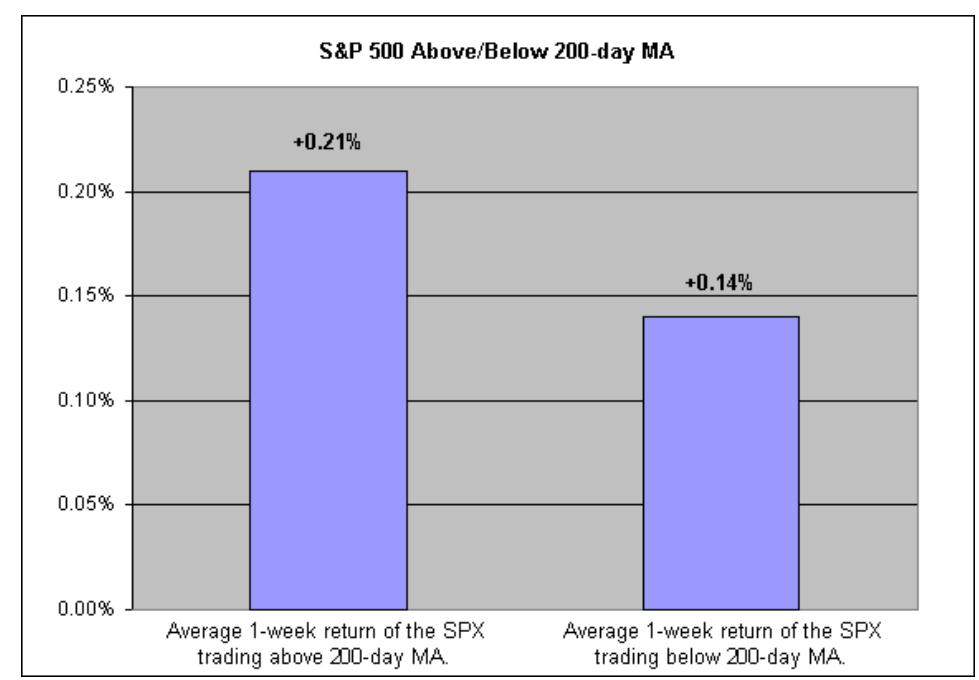

Obtain from

Figure 1. Returns using 200 dma (SPX)

http://www.tradingmarkets.com/site/stocks/commentary/editorial/200day-moving-average.cfm

\section{Buy and Hold strategy}

Buy and Hold strategy is the long-term investment strategy. The investor selects the stock that looked profitable then buy the stock and hold it for long-term period and in this study is one year period. This strategy will ignore short term noise.

\section{Random Walk Theory}

The theory that assumes that the stock price behaves randomly and the future stock trend cannot be predicted based on the past history stock trend (Gray et.al.2004).This also means that as market is efficient and all available information has been reflected in the current stock price, fundamental and technical analysis cannot help to outperform the market.

\section{RESEARCH METHODOLOGY}

From the previous chapters, the author has explained the general understranding about the PE ratio and the Day Moving Average indicators that can help the investor to make a buying or selling decision. The PE is 
calculated by dividing the price and the earning per share. The information about the earning can be found in the companys' financial statement. Many investor make a buying or selling decision just based on news, instinct, or just following their friend's decision. In fact, there are tools that can help investor to make a buying or selling decision. The tools can be fundamental analyses and technical analyses. This research will focus on the Price earning ratio and Day Moving Average (DMA) to produce the findings that have been conducted previosly by using these two factors. Using the different time and market, the author wants to test the relationship of PE and DMA indicators to the stock market returns.

\section{Research hypothesis and Aim}

This study is an explanatory attempting to explain a relationship between two variables in which the changes in one variable can give a different result on another variable. According to Aaler and Day (1990), the explanatory study is used to show that one variable determines the value of other variable. In this case the variables of PE and DMA determines the different level of returns.

\section{Research approach}

This study is a quantitative research since the study uses and produces numerical data and transform into quantifiable numbers. The quantitative research is claimed to be associated with the analyses since it can make a comparison and a correlation to get the results.

This study is performed to answer the following questions:

- Do the low PE strategy can give a greater return compare using buy and hold strategy

- Do the combination between low PE strategy and above 200 DMA can give a greater return compare using buy and hold strategy

\section{Time and place}

The research is conducted from January 2005 to December 2009. All the information were gathered from the Indonesia Stock Exchange, Bloomberg, Index BEJ, or the official website of the companies. This is a cross-sectional studies since comparing the data at the same point of time. 


\section{RESEARCH DESIGN}

\section{The purpose of the study}

The author decides to combine the low PE ratio and 200 DMA in order to find the undervalue stocks that the trend starts to move upward. The study of low PE ratio has been conducted in several countries such as New Zealand, Greece, thus, the author decides to conduct the research to find out whether the combination of that two theory is applicable in Indonesia or not.

The moving average cannot be the only indicator to buy or to sell because moving average cannot find the undervalue stock. It is used to know the trend of the market, thus, it cannot be the sole comparison of the other strategy.

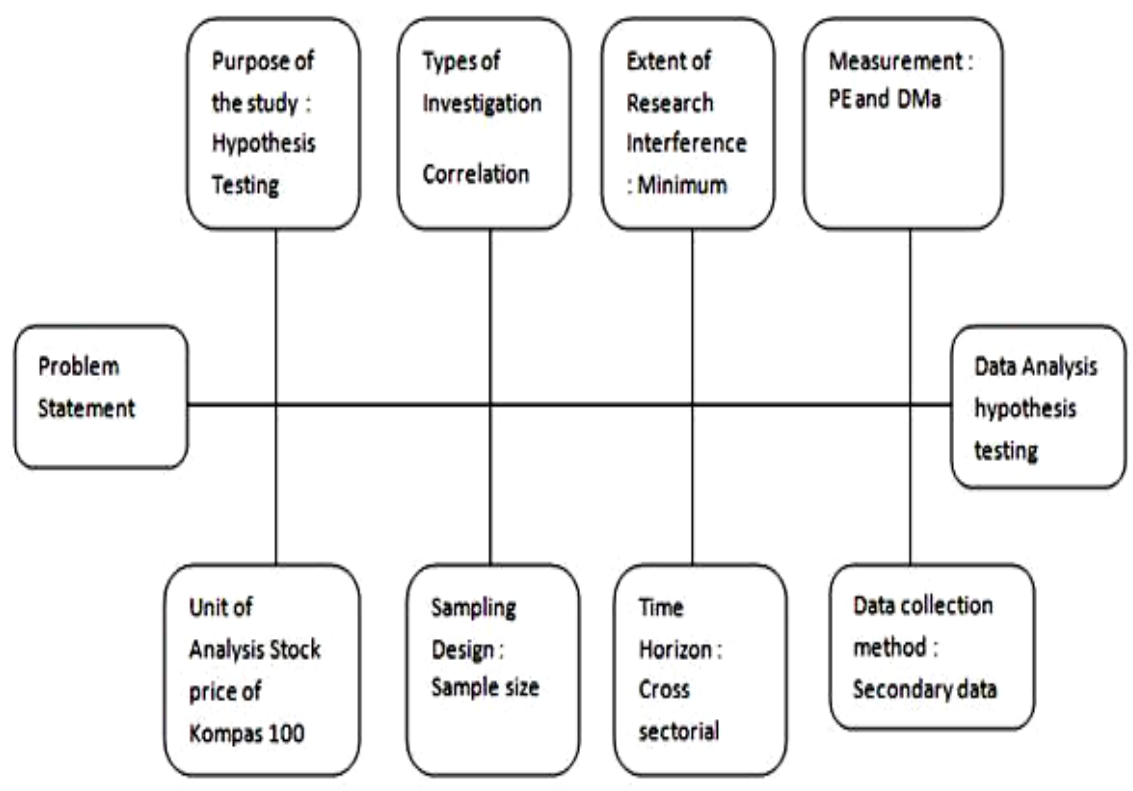

Figure 2. Research Design

Source : Sekaran (2003)

\section{The Type of Data Used in The Research}

The data used are taken from the (financial statement of the company and the stock prices that are included in the 28 of 100 liquid companies from 
2005 until 2009. The 28 companies are chosen among Kompas 100 due to availability data on the 5 years average PE . Bloomberg is chosen as one of the data source because it provides all the information needed such as market price from 2005 until 2009 and Price Earning ratio.

\section{Method of Gathering Data}

The literature reviews are being conducted as part of the preliminary data gathering. To what we can conclude, all the necessary and relevant theories required to enhance the author understanding over the issue will be provided by the literature review. The literature review can be journals, articles, and websites that provides all the information needed for this research.

The secondary data which are gathered from the other resources are collected from Bloomberg, Binus database and the company's website.

\section{Sampling Design}

The author decides to use companies from kompas 100 that are listed in the Indonesia stock exchange from year 2005 until 2009. In order to get more accurate results, the author decides to benchmark to the 28 company that have 10 years records of stock prices, earnings. The author will select the stock from the first rank of Kompas 100. However, if the data is not complete, the author will choose the following rank. Kompas 100 is the list of stocks that are listed in BEI which have high liquidity, big capitalization, and good fundamental.

\section{DATA ANALYSES AND INTERPRETATION}

\section{Descriptive analyses}

The Microsoft Excel will be performed in order to get an answer whether the $\mathrm{PE}$ ratio can be an indicator of buying-selling decision. First, the author collect the market price of the sample company from 2005 until 2009, then to calculate the price earnings ratio, the author needs to get the trailing EPS. In order to find the low PE ratio, the investor need to compare the ratio to the historical $\mathrm{PE}$ or competitor within the same industry, in this study, the author decides to compare the PE ratio to its 5 years historical PE. If the PE is below the 5 years historical PE, it is an indicator of buying decision because it means that the stock is 
underpriced, on the other hand, if the price is over the 5 years historical $\mathrm{PE}$, it can be interpreted that that stock is overpriced which mean the time of selling decision.

There is another method that the author tries to compare. It is using the combination of low PE and 200 DMA. The 200 DMA is the average of 200 previous days market price. The DMA is used to know the momentum trend of the market. If PE is below 5 years average PE and the stock price is above 200DMA, it signals a buy decision. If $\mathrm{PE}$ is above its 5 years average PE or the stock price is below its 200 DMA, it signals a sell decision.

The reason why the sell signal just need to fulfill one condition are:

-If the PE is above 5 years PE, it means that the stock price is not cheap anymore so it does not need to wait for the other condition

-On the other hand, if the price is below 200 DMA, the upside momentum may have ended so we do not want to own the stock anymore.

In this study, lets assume that the investor allocates Rp. 10 million to invest in any single stock. If there is a buy signal of PE strategy, the investor will buy the stock that worth Rp. 10 millions. Then, the investor get some number of shares that worth 10 million. If there is a sell signal, the investor will sell all shares that he has. At the end of the year, we will calculate the percentage return from that Rp. 10 million investment. We do this simulation for each company. At the end of the year, we will calculate the average return from the 28 companies. There is some case that there is still no sell signal in that year, in order to compare with 1 year holding period, although there is no sell signal until the end of the year, the stock should be sold in the end of the year and buy it again with the price at the beginning of the next year.

For example, BLTA, in 2005, there was a buy signal when the price at Rp589, then the investor bought stocks at that price that worth 10 millions, so the investor got 16,977 shares. After that, there was a sell signal at Rp659, so the investor should sell all the shares at that prices, and would get the revenue for $\mathrm{Rp} 11,188,455$. Then, there was a buy signal again at Rp745, the investor bought the shares at that price with Rp11,188,455 , and would get 15,018 shares. There was a sell signal again at Rp893, the investor sold all his stocks at that price and would get Rp13,411,128. There was a last buy signal in that year at Rp901, so the investor bought the shares at that price with Rp13,411,128 revenue. The investor got 
14,844 shares. In that year, there is no sell signal anymore, so to compare with Buy \& Hold 1 year holding period, the stocks should be sold at the end of that year with the price at 901, so the investors will get Rp13,411,128. Then, to get the percentage return for that year, the last revenue which is $R p 13,411,128$ would be reduced with the initial capital which is Rp10,000,000 and will be divided by Rp10,000,000. Therefore, the PE strategy would result in $34 \%$ return in that year.

After finding the return for all 28 companies, the return would be averaged by adding all the returns of 28 companies then divided by 28 companies. So there would be 5 years returns for all 3 strategies. Furthermore, to find the overall returns, the returns from 2005-2009 will be summed up than divided by 5 years. So there will be 3 average returns for 3 strategis of 28 companies.

\section{Paired-samples T - test}

Paired-Samples $\mathrm{T}$ test is using to compare the mean from two samples. From the result, the author will get the $\mathrm{P}$ value that is used to know whether to reject or accept the hypothesis and whether the difference is significant or not.

\section{FINDINGS AND DISCUSSIONS}

In this research, the author decides to take 28 companies out of 100 companies from the kompas 100 as samples. Bloomberg shows that only 28 companies have the necessary data that we need. The time horizon is 5 years from 2005 to 2009.

\section{Descriptive Analyses}

In 2005, the PE strategy yielded 18,02 \% while the Buy and Hold strategy's return gave a lower return of 13,70\%. In 2006, the PE strategy resulted in 23,23\% return which an increase from year 2005, but with Buy and Hold strategy, the investor can get 70,05\% return for holding 28 stocks in that year. In 2007, although the PE strategy can give a nice return of $40,21 \%$, but the Buy and Hold strategy even gave larger return of $71,81 \%$. In 2008, when the crisis struck worldwide, the price of stocks went down sharply causing Buy and Hold strategy a negative return of - 
$49,24 \%$ to the investor. However, using low PE strategy, the impact of the crisis can be somewhat minimized resulting in a negative return of $23,60 \%$ to the investors. In 2009, Indonesia economy gradually recovered from the crisis and Buy and Hold strategy came back to be the winner after giving $113,43 \%$ return compare to the PE strategy that only gave $43,84 \%$ return.

Table 1. The time horizon is 5 years from 2005 to 2009

\begin{tabular}{|l|l|l|l|}
\hline Year & $\begin{array}{l}\text { Average } \\
\text { returns using } \\
\text { PE strategy }\end{array}$ & $\begin{array}{l}\text { Average } \\
\text { returns using } \\
\text { PEDMA } \\
\text { strategy }\end{array}$ & $\begin{array}{l}\text { Average } \\
\text { Return using } \\
\text { Buy and Hold } \\
\text { strategy }\end{array}$ \\
\hline 2005 & $18,02 \%$ & $7,56 \%$ & $13,70 \%$ \\
\hline 2006 & $23,23 \%$ & $11,72 \%$ & $70,05 \%$ \\
\hline 2007 & $40,21 \%$ & $28,60 \%$ & $71,81 \%$ \\
\hline 2008 & $(23,60 \%)$ & $(4,91 \%)$ & $(49,24 \%)$ \\
\hline 2009 & $43,84 \%$ & $11,25 \%$ & $113,43 \%$ \\
\hline Average & $20,34 \%$ & $10,84 \%$ & $43,95 \%$ \\
\hline
\end{tabular}

For the comparison with PEDMA strategy, in 2005, the PEDMA strategy resulted in 7,56 \% profit to the investors but using Buy and Hold strategy, the profit is almost doubled which is over $13 \%$. The following year the profit from PEDMA strategy increased to $11,72 \%$ while the return from Buy and Hold strategy was over 70\%. In 2007, the return from PEDMA increased sharply to $28,60 \%$, while the profit from buy and hold strategy also increased to $71,81 \%$. In the year of crisis, year 2008, using Buy and Hold strategy gave a huge loss almost $50 \%$, while using PEDMA strategy, the loss can be minimalized to only 4,91\%. In the following year, 2009, the profit from Buy and Hold strategy get back on the track which gave returns around 113,43\%, in a meantime, the profit from PEDMA just around $11 \%$. 
The price of all stocks is keep increasing after 2005 because of some factors such as the indonesia economy growth is increasing and the period of bullish market. This condition makes the strategy of low pe and combination of pe\&dma cannot beat the Buy and Hold strategy sincethe buying parameter of both strategy requires $\mathrm{PE}$ to fall below 5 years average PE and once the investor sell the stock, its difficult to get back in.

In year 2005, generally, Buy and Hold strategy gave a higher return. However, the performance of some stocks in that year is quite flat resulting in a dramatic outperformance of other strategies (PE and PEDMA) over Buy and Hold strategy. Because of this dramatic outperformance, it skewed the overall average result on the stocks covered in this study. Thus, PE and PEDMA strategy beat Buy and Hold strategy for this reason.

There is a special case in 2008 which the PE and PEDMA can beat the Buy and Hold strategy significantly. Using these tow strategies, the loss can be minimalized compare if using Buy and Hold strategy because in this year, the price of the stocks was falling sharply due to some factors such as subprime mortgage, Madoc fraud, that make many big company in the world was suffering losses and some was bankrucpt. These has an impact to the indonesian economy too which make almost all company was suffering a big loss that make the stock was decreasing sharply.

\section{Hypothesis Testing}

This research want to analyze the three strategy which can give the biggest return to the investor. The t- test will be performed to know the result

\section{Hypothesis 1}

Ho : there is no significance difference in return between $\mathrm{PE}$ and $\mathrm{B} \& \mathrm{H}$

$\mathrm{H}_{1}$ : there is a significance difference in return between $\mathrm{PE}$ and $\mathrm{B} \& H$

\begin{tabular}{|l|l|l|l|l|}
\hline 2005 & 2006 & 2007 & 2008 & 2009 \\
\hline 0,21543 & $5,68 \mathrm{E}-05$ & 0,01638 & $2,31 \mathrm{E}-05$ & 0,00019 \\
\hline
\end{tabular}

From 2005 to 2009, only in 2005 that the Ho cannot be rejected since the P-value is bigger than 0,05. From 2006 to 2009, there is strong evidence to infer that the Ho is rejected since the P-value after divided by two, is smaller than 0,05 . 


\section{Hypothesis 2}

Ho : there is no significance difference in return between PEDMA and $\mathrm{B} \& \mathrm{H}$

$\mathrm{H}_{1}$ : there is a significance difference in return between PEDMA and $\mathrm{B} \& \mathrm{H}$

\begin{tabular}{|l|l|l|l|l|}
\hline 2005 & 2006 & 2007 & 2008 & 2009 \\
\hline 0,10774 & $7,56 \mathrm{E}-07$ & 0,00289 & $3,11 \mathrm{E}-08$ & $2,09 \mathrm{E}-06$ \\
\hline
\end{tabular}

From 2005 to 2009, only in 2005 that the Ho cannot be rejected since the P-value is bigger than 0,05. From 2006 to 2009, there is strong evidence to infer that the Ho is rejected since the P-value after divided by two, is smaller than 0 .

\section{CONCLUSION, LIMITATIONS, AND RECOMMENDATIONS}

\section{Conclussion}

This research is conducted to know whether the low PE strategy or PEDMA strategy can give high returns that can beat Buy and Hold strategy. In this study, the author uses 28 companies that are listed in kompas100.

Many previous studies that are conducted in several countries prove that the low PE strategy can give significant returns to the investors. However, from the result of this study, although the low PE strategy can give postive returns to the investor but it cannot beat the buy and hold strategy.

The Buy and Hold strategy gives return that are significant if it is comparing to the PE and PEDMA strategy. The low PE strategy cannot be a good indicator if the market is in the bull condition. However, in some condition, for example in 2008, where the world is in the crisis after subprime mortgage happened in USA, the Buy and Hold gives big negative returns since the price of the stocks was decreasing sharply. On the other hand, the PE and PEDMA strategy still can give a positive returns.

\section{Limitations:}

1. The time horizon should be more than 1 year because sometimes there is still no sell signal in that year, but in the test, the stock should be 
sold in the end of the year to make year by year comparison

2. The company data, there are some companies which their data is hard to obtain. The company sometimes is not transparant a to the public so it is hard for investors to get the data.

\section{Recommendation}

- The PE alone cannot be the only parameter to generate buying or selling signal, there must have several parameters to strengthen the $\mathrm{PE}$ parameter.

- The parameter of the low PE can be adjusted for example the investor buy if the PE is $20 \%$ below 5 years average pe and sell the stock if the $\mathrm{PE}$ is $20 \%$ above 5 years average $\mathrm{PE}$.

- The time horizon shoud be more than 1 year. So the result will be more accurate since the investor will follow the buy or sell order. The investor is not required to sell their stock in the end of the year althought there is still no sell signal.

- For further study, the sample can be changed to small caps company. So the investor will know whether which strategy is more profitable.

\section{REFERENCES}

Basu, S. (1977). Investment performance of common stocks in relation to their price-earning ratios: A test of the efficient market hypothesis. Journal of Finance, 32, 663-682.

Beddard, Richard. (2009). The long-term PE. Retrieved April 10, 2010, from http://blog.iii.co.uk/ltpe/

Benett, Tim. (2007). What you need to know about the p/e ratio. Retrieved April 25, 2010, from http://www.moneyweek.com/investmentadvice/how-to-invest/what-you-need-to-know-about-the-peratio.aspx

Brigham, E.J., \& Gapenski L.C. (1993). Intermediate Financial Management. (4 ed.). New York: The Dryden Press. 
Brealy, Richard A., Myers. Stewart C. (1996). Principle in corporate finance $\left(5^{\text {th }}\right.$ ed.). New York: Mcgraw-Hill, inc.

Campbell, John Y., \& Robert J. Shiller. (1988). Stock Prices, Earnings, and Expected Dividends. Journal of Finance, 43(3): 661-76.

Connors, Larry. (2007). Why Every Trader Needs to Watch the 200-Day Moving Average. Retrieved March 1, 2010, from http://www.tradingmarkets.com/.site/stocks/commentary/editorial/ 200-day-moving-average.cfm

Fama, Eugene F., \& Kenneth R. French. (1992, April). The Cross Section of Expected Stock Returns. The Journal of Finance, 47(2), April, 427-465.

Gray, G., Cusatis, Patrick J., Woolridge, J. Randall. (2004). Streetsmart Guide to Valuing a Stock: The Savvy Investors Key to Beating the Market.New York: McGraw Hill.

Graham, Benjamin, \& David L. Dodd. (1934). Security Analysis (1st ed.). New York: McGraw Hill

Jaffe, J., D. B. Keim, \& R. Westerfield (1989). Earnings Yields, Market Values, and Stock Returns. Journal of Finance, 44, 135- 148.

Loth, Richard. (1999). Select Winning Stocks Using Financial Statements. Chicago: Dearborn.

Malhotra, Amit. (2007). Factors Affecting Share Prices. Retrieved April 25, 2010, from http://ezinearticles.com/?Factors-Affecting-SharePrices\&id=741674

Moving Averages. Retrieve March 6, 2010, from http://finviz.com/help/technical-analysis/moving-averages.ashx

Moving Average. Retrieve March 6, 2010, from http://web.streetauthority.com/terms/movingaverages.asp 
Moving Average. Retrieve March 6, 2010, from http://200dma.com/

Nicholson, S.F. (1960). Price-Earnings Ratios. Financial Analysts Journal, 16(4): 43-45.

Price-earning ratio. Retrieve March, 25. 2010, from http://marketlive.in/stock-market-tutorials/price-to-earnings-peratio.php

Sekaran, U. (2003). Research Methods for Business: A Skill Building Approach $\left(2^{\text {nd }}\right.$ ed.). New York: John Wiley and Son.

Seyhun, H. Nejat. (2000). Investment Intelligence from insider trading. Massachusetts: The MIT Press

Smith, David. (2008). The 10 Factors That Affect and Predict Stock Prices. Retrieved March 23, 2010, from http://www.articlesbase.com/investing-articles/the-10-factors-thataffect-and-predict-stock-prices-617610.html

Thomas, John B. (May 23,1994). P/E Ratios Driven by Variety of Factors, Carry Variety of Meanings. Indianapolis Business Journal, 10B.

Truong, H.A. (2009). Value investuing using price-earning ratio in New Zealand. University of Auckland Business review, 11(1). 


\section{APPENDICES}

\section{A. List of Some Samples Calculation}

\section{AALI \\ PE}

\begin{tabular}{|l|ll|l|}
\hline \multicolumn{4}{|c|}{2005} \\
\hline Rp 10.000.000 & Rp & 3.075 & 3252,033 \\
\hline Rp 11.707.317 & Rp & 3.600 & 3252,033 \\
\hline
\end{tabular}

\begin{tabular}{|ll|l|l|}
\hline \multicolumn{4}{|c|}{2008} \\
\hline Rp & 16.636 .013 & Rp 27.000 & 616,1486 \\
\hline Rp & 18.268 .807 & Rp 29.650 & 616,1486 \\
\hline Rp & 18.268 .807 & Rp 26.000 & 702,6464 \\
\hline Rp & 6.885 .935 & Rp 9.800 & 702,6464 \\
\hline
\end{tabular}

\begin{tabular}{|l|c|r|}
\hline \multicolumn{4}{|c|}{2007} \\
\hline Rp 11.707.317 & Rp 12.250 & 955,6994 \\
\hline Rp 12.854.156 & Rp 13.450 & 955,6994 \\
\hline Rp 12.854.156 & Rp 13.050 & 984,9928 \\
\hline Rp 13.198.904 & Rp 13.400 & 984,9928 \\
\hline Rp 13.198.904 & Rp 16.800 & 785,649 \\
\hline Rp 15.477.286 & Rp 19.700 & 785,649 \\
\hline Rp 15.477.286 & Rp 18.700 & 827,6624 \\
\hline Rp 16.636.013 & Rp 20.100 & 827,6624 \\
\hline
\end{tabular}

\begin{tabular}{|ll|l|l|}
\hline \multicolumn{4}{|c|}{2009} \\
\hline$R p$ & 6.885 .935 & $\operatorname{Rp~} 11.750$ & 586,037 \\
\hline$R p$ & 8.526 .839 & $\operatorname{Rp~} 14.550$ & 586,037 \\
\hline
\end{tabular}

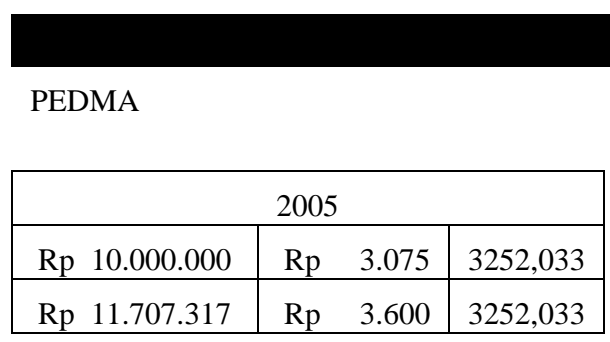

\begin{tabular}{|l|l|l|}
\hline \multicolumn{4}{|c|}{2008} \\
\hline Rp 14.756.004 & Rp 27.000 & 546,5187 \\
\hline Rp 16.204.279 & Rp 29.650 & 546,5187 \\
\hline Rp 16.204.279 & Rp 26.000 & 623,2415 \\
\hline
\end{tabular}

\begin{tabular}{|l|c|c|}
\hline \multicolumn{3}{|c|}{2007} \\
\hline Rp 11.707.317 & $\operatorname{Rp~16.800~}$ & 696,8641 \\
\hline Rp 13.728.223 & $\operatorname{Rp~19.700~}$ & 696,8641 \\
\hline Rp 13.728.223 & $\operatorname{Rp~18.700~}$ & 734,1296 \\
\hline Rp 14.756.004 & Rp 20.100 & 734,1296 \\
\hline
\end{tabular}




\begin{tabular}{|c|c|c|} 
Rp 12.932.261 & Rp 20.750 & 623,2415 \\
\hline Rp 12.932.261 & Rp 23.000 & 562,2722 \\
\hline Rp 14.225.487 & Rp 25.300 & 562,2722 \\
\hline
\end{tabular}

\section{ASII}

PE

\begin{tabular}{|c|c|c|}
\hline \multicolumn{3}{|c|}{2005} \\
\hline Rp 10.000 .000 & $\begin{array}{ll}\mathrm{Rp} & 9.600 \\
\end{array}$ & 1041,667 \\
\hline Rp 10.468.750 & Rp 10.050 & 1041,667 \\
\hline Rp 10.468 .750 & $\begin{array}{ll}\mathrm{Rp} & 9.500 \\
\end{array}$ & 1101,974 \\
\hline Rp 11.680.921 & Rp 10.600 & 1101,974 \\
\hline Rp 11.680.921 & Rp 10.300 & 1134,07 \\
\hline Rp 12.021.142 & Rp 10.600 & 1134,07 \\
\hline Rp 12.021.142 & Rp 10.300 & 1167,101 \\
\hline Rp 11.904.432 & Rp 10.200 & 1167,101 \\
\hline
\end{tabular}

\begin{tabular}{|c|c|c|}
\hline \multicolumn{3}{|c|}{2006} \\
\hline Rp 11.904.432 & Rp 10.100 & 1178,657 \\
\hline Rp 12.022.298 & Rp 10.200 & 1178,657 \\
\hline Rp 12.022.298 & Rp 9.800 & 1226,765 \\
\hline Rp 12.513.004 & Rp 10.200 & 1226,765 \\
\hline Rp 12.513.004 & Rp 10.100 & 1238,911 \\
\hline Rp 13.070.514 & Rp 10.550 & 1238,911 \\
\hline Rp 13.070.514 & Rp $\quad 9.800$ & 1333,726 \\
\hline Rp 13.604.004 & Rp 10.200 & 1333,726 \\
\hline Rp 13.604.004 & Rp $\quad 9.800$ & 1388,164 \\
\hline 534. & 9.750 & 1388,1 \\
\hline
\end{tabular}

\begin{tabular}{|l|l|l|}
\hline \multicolumn{4}{|c|}{2008} \\
\hline Rp 13.534.596 & Rp 24.900 & 543,5581 \\
\hline Rp 14.078.154 & Rp 25.900 & 543,5581 \\
\hline Rp 14.078.154 & Rp 24.800 & 567,6675 \\
\hline Rp 14.447.138 & Rp 25.450 & 567,6675 \\
\hline Rp 14.447.138 & Rp 24.500 & 589,6791 \\
\hline Rp 14.918.881 & Rp 25.300 & 589,6791 \\
\hline Rp 14.918.881 & Rp 23.550 & 633,4981 \\
\hline Rp 6.683.405 & Rp 10.550 & 633,4981 \\
\hline
\end{tabular}

\begin{tabular}{|ll|l|l|}
\hline \multicolumn{4}{|c|}{2009} \\
\hline$R p$ & 6.683 .405 & $R p 12.200$ & 547,8201 \\
\hline$R p$ & 9.860 .762 & $R p 18.000$ & 547,8201 \\
\hline$R p$ & 9.860 .762 & $R p 17.700$ & 557,1052 \\
\hline$R p$ & 10.334 .301 & $R p 18.550$ & 557,1052 \\
\hline
\end{tabular}

PEDMA

\begin{tabular}{|l|l|l|}
\hline \multicolumn{4}{|c|}{2008} \\
\hline Rp 10.000.000 & Rp 24.900 & 401,6064 \\
\hline Rp 10.401.606 & Rp 25.900 & 401,6064 \\
\hline
\end{tabular}

\begin{tabular}{|lr|c|r|}
\hline \multicolumn{4}{|c|}{2009} \\
\hline Rp 10.039 .853 & $\operatorname{Rp~} 15.250$ & 658,351 \\
\hline Rp & 9.381 .502 & $\operatorname{Rp} 14.250$ & 658,351 \\
\hline
\end{tabular}

20)

Alvin, A. \& Triasurya, D. / Journal of Applied Finance and Accounting 3(1) 1-34 


\begin{tabular}{|l|l|l|} 
Rp 10.401.606 & Rp 24.800 & 419,4196 \\
\hline Rp 10.674.229 & Rp 25.450 & 419,4196 \\
\hline Rp 10.674.229 & Rp 24.500 & 435,6828 \\
\hline Rp 11.022.775 & Rp 25.300 & 435,6828 \\
\hline Rp 11.022.775 & Rp 23.550 & 468,0584 \\
\hline Rp 10.039.853 & Rp 21.450 & 468,0584 \\
\hline
\end{tabular}

\begin{tabular}{|c|c|c|}
\hline Rp $\quad 9.381 .502$ & Rp 15.450 & 607,2169 \\
\hline $\begin{array}{ll}\text { Rp } & 8.895 .728 \\
\end{array}$ & Rp 14.650 & 607,2169 \\
\hline $\begin{array}{ll}\text { Rp } & 8.895 .728 \\
\end{array}$ & Rp 15.250 & 583,3264 \\
\hline Rp 10.499.876 & Rp 18.000 & 583,3264 \\
\hline Rp 10.499.876 & Rp 17.700 & 593,2133 \\
\hline Rp 11.004.107 & Rp 18.550 & 593,2133 \\
\hline
\end{tabular}

\section{ANTM}

PE

\begin{tabular}{|l|ll|l|}
\hline \multicolumn{5}{|c|}{2005} \\
\hline Rp 10.000.000 & Rp & 346 & 28901,73 \\
\hline Rp 13.583.815 & Rp & 470 & 28901,73 \\
\hline Rp 13.583.815 & Rp & 440 & 30872,31 \\
\hline Rp 14.509.984 & Rp 470 & 30872,31 \\
\hline Rp 14.509.984 & Rp 455 & 31890,08 \\
\hline Rp 14.669.435 & Rp 460 & 31890,08 \\
\hline Rp 14.669.435 & Rp & 395 & 37137,81 \\
\hline Rp 15.969.258 & Rp 430 & 37137,81 \\
\hline Rp 15.969.258 & Rp 490 & 32590,32 \\
\hline Rp 16.295.161 & Rp 500 & 32590,32 \\
\hline
\end{tabular}

\begin{tabular}{|l|l|l|}
\hline \multicolumn{4}{|c|}{2008} \\
\hline Rp 39.122.732 & Rp 3.700 & 10573,71 \\
\hline Rp 41.237.475 & Rp 3.900 & 10573,71 \\
\hline Rp 41.237.475 & Rp 3.550 & 11616,19 \\
\hline Rp 44.722.332 & Rp 3.850 & 11616,19 \\
\hline Rp 44.722.332 & Rp 3.600 & 12422,87 \\
\hline Rp 41.616.614 & Rp 3.350 & 12422,87 \\
\hline Rp 41.616.614 & Rp 3.225 & 12904,38 \\
\hline Rp 44.842.708 & Rp 3.475 & 12904,38 \\
\hline Rp 44.842.708 & Rp 3.225 & 13904,72 \\
\hline Rp 46.580.798 & Rp 3.350 & 13904,72 \\
\hline
\end{tabular}

\begin{tabular}{|c|c|c|}
\hline \multicolumn{3}{|c|}{2007} \\
\hline Rp 16.295.161 & Rp 1.560 & 10445,62 \\
\hline Rp 16.817.442 & Rp 1.610 & 10445,62 \\
\hline Rp 16.817.442 & Rp 1.580 & 10643,95 \\
\hline Rp 17.243.200 & Rp 1.620 & 10643,95 \\
\hline Rp 17.243.200 & Rp 1.590 & 10844,78 \\
\hline Rp 19.086.813 & Rp 1.760 & 10844,78 \\
\hline Rp 19.086.813 & Rp 2.370 & 8053,507 \\
\hline Rp 22.871.961 & Rp 2.840 & 8053,507 \\
\hline Rp 22.871.961 & Rp 2.480 & 9222,565 \\
\hline Rp 24.532.023 & Rp 2.660 & 9222,565 \\
\hline Rp 24.532.023 & Rp 2.600 & 9435,393 \\
\hline Rp 24.909.438 & Rp 2.640 & 9435,393 \\
\hline Rp 24.909.438 & Rp 2.610 & 9543,846 \\
\hline Rp 25.386.631 & Rp 2.660 & 9543,846 \\
\hline Rp 25.386.631 & Rp 2.570 & 9878,066 \\
\hline Rp 25.386.631 & Rp 2.570 & 9878,066 \\
\hline Rp 25.386.631 & Rp 2.540 & 9994,737 \\
\hline Rp 25.786.420 & Rp 2.580 & 9994,737 \\
\hline Rp 25.786.420 & Rp 2.400 & 10744,34 \\
\hline Rp 27.666.680 & Rp 2.575 & 10744,34 \\
\hline Rp 27.666.680 & Rp 2.525 & 10957,1 \\
\hline Rp 29.036.318 & Rp 2.650 & 10957,1 \\
\hline Rp 29.036.318 & Rp 2.775 & 10463,54 \\
\hline
\end{tabular}




\begin{tabular}{|l|l|l|} 
Rp 46.580.798 & Rp 3.325 & 14009,26 \\
\hline Rp 47.281.261 & Rp 3.375 & 14009,26 \\
\hline Rp 47.281.261 & Rp 3.300 & 14327,65 \\
\hline Rp 15.617.144 & Rp 1.090 & 14327,65 \\
\hline
\end{tabular}

\begin{tabular}{|l|l|l|} 
Rp 35.837.617 & Rp 3.425 & 10463,54 \\
\hline Rp 35.837.617 & Rp 3.000 & 11945,87 \\
\hline Rp 39.122.732 & Rp 3.275 & 11945,87 \\
\hline
\end{tabular}

\begin{tabular}{|l|l|l|}
\hline \multicolumn{4}{|c|}{2009} \\
\hline Rp 15.617.144 & Rp 1.230 & 12696,86 \\
\hline Rp 15.617.144 & Rp 1.230 & 12696,86 \\
\hline Rp 15.617.144 & Rp 1.180 & 13234,87 \\
\hline Rp 16.278.887 & Rp 1.230 & 13234,87 \\
\hline Rp 16.278.887 & Rp 1.160 & 14033,52 \\
\hline Rp 17.541.904 & Rp 1.250 & 14033,52 \\
\hline Rp 17.541.904 & Rp 1.150 & 15253,83 \\
\hline Rp 18.762.211 & Rp 1.230 & 15253,83 \\
\hline Rp 18.762.211 & Rp 1.200 & 15635,18 \\
\hline Rp 17.042.341 & Rp 1.090 & 15635,18 \\
\hline
\end{tabular}

\section{ANTM}

PEDMA

\begin{tabular}{|l|lll|l|}
\hline \multicolumn{5}{|c|}{2005} \\
\hline $\mathrm{Rp} 10.000 .000$ & $\mathrm{Rp}$ & 346 & 28901,73 \\
\hline $\mathrm{Rp} 13.583 .815$ & $\mathrm{Rp}$ & 470 & 28901,73 \\
\hline $\mathrm{Rp} 13.583 .815$ & $\mathrm{Rp}$ & 440 & 30872,31 \\
\hline $\mathrm{Rp} 14.509 .984$ & $\mathrm{Rp}$ & 470 & 30872,31 \\
\hline $\mathrm{Rp} 14.509 .984$ & $\mathrm{Rp}$ & 455 & 31890,08 \\
\hline $\mathrm{Rp} 14.669 .435$ & $\mathrm{Rp}$ & 460 & 31890,08 \\
\hline $\mathrm{Rp} 14.669 .435$ & $\mathrm{Rp}$ & 490 & 29937,62 \\
\hline $\mathrm{Rp} 14.968 .811$ & $\mathrm{Rp}$ & 500 & 29937,62 \\
\hline
\end{tabular}

\begin{tabular}{|l|c|c|}
\hline \multicolumn{4}{|c|}{2008} \\
\hline Rp 31.727.579 & Rp 3.700 & 8575,021 \\
\hline Rp 25.081.938 & Rp 2.925 & 8575,021 \\
\hline
\end{tabular}

\begin{tabular}{|l|c|c|}
\hline \multicolumn{4}{|c|}{2007} \\
\hline Rp 14.968.811 & Rp 1.560 & 9595,392 \\
\hline Rp 15.448.580 & Rp 1.610 & 9595,392 \\
\hline Rp 15.448.580 & Rp 1.580 & 9777,583 \\
\hline Rp 15.839.684 & Rp 1.620 & 9777,583 \\
\hline Rp 15.839.684 & Rp 1.590 & 9962,065 \\
\hline Rp 17.533.235 & Rp 1.760 & 9962,065 \\
\hline Rp 17.533.235 & Rp 2.370 & 7397,989 \\
\hline Rp 21.010.290 & Rp 2.840 & 7397,989 \\
\hline Rp 21.010.290 & Rp 2.480 & 8471,891 \\
\hline Rp 22.535.230 & Rp 2.660 & 8471,891 \\
\hline Rp 22.535.230 & Rp 2.600 & 8667,396 \\
\hline Rp 22.881.926 & Rp 2.640 & 8667,396 \\
\hline Rp 22.881.926 & Rp 2.610 & 8767,021 \\
\hline
\end{tabular}

22) 


\begin{tabular}{|c|c|c|}
\hline Rp 25.081.938 & Rp 3.375 & 7431,685 \\
\hline Rp 28.983.572 & Rp 3.900 & 7431,685 \\
\hline Rp 28.983.572 & Rp 3.550 & 8164,387 \\
\hline Rp 31.432.888 & Rp 3.850 & 8164,387 \\
\hline Rp 31.432.888 & Rp 3.600 & 8731,358 \\
\hline Rp 28.595.197 & Rp 3.275 & 8731,358 \\
\hline Rp 28.595.197 & Rp 3.425 & 8348,963 \\
\hline Rp 27.969.025 & Rp 3.350 & 8348,963 \\
\hline
\end{tabular}

\begin{tabular}{|c|c|c|}
\hline Rp 23.320.277 & Rp 2.660 & 8767,021 \\
\hline Rp 23.320.277 & Rp 2.570 & 9074,038 \\
\hline Rp 23.320.277 & Rp 2.570 & 9074,038 \\
\hline Rp 23.320.277 & Rp 2.540 & 9181,211 \\
\hline Rp 23.687.526 & Rp 2.580 & 9181,211 \\
\hline Rp 23.687.526 & Rp 2.400 & 9869,802 \\
\hline Rp 25.414.741 & Rp 2.575 & 9869,802 \\
\hline Rp 25.414.741 & Rp 2.525 & 10065,24 \\
\hline Rp 21.137.012 & Rp 2.100 & 10065,24 \\
\hline Rp 21.137.012 & Rp 2.250 & 9394,228 \\
\hline Rp 20.667.301 & Rp 2.200 & 9394,228 \\
\hline Rp 20.667.301 & Rp 2.250 & 9185,467 \\
\hline Rp 20.437.664 & Rp 2.225 & 9185,467 \\
\hline Rp 20.437.664 & Rp 2.300 & 8885,941 \\
\hline Rp 23.547.744 & Rp 2.650 & 8885,941 \\
\hline Rp 23.547.744 & Rp 2.775 & 8485,673 \\
\hline Rp 29.063.431 & Rp 3.425 & 8485,673 \\
\hline Rp 29.063.431 & Rp 3.000 & 9687,81 \\
\hline Rp 31.727.579 & Rp 3.275 & 9687,81 \\
\hline
\end{tabular}

\section{BBCA}

PE
\begin{tabular}{|l|c|c|}
\hline \multicolumn{3}{|c|}{2005} \\
\hline Rp 10.000.000 & Rp 1.613 & 6199,628 \\
\hline Rp 10.229.386 & Rp 1.650 & 6199,628 \\
\hline
\end{tabular}

\begin{tabular}{|l|l|l|}
\hline \multicolumn{4}{|c|}{2008} \\
\hline Rp 12.220.928 & Rp 2.975 & 4107,875 \\
\hline Rp 13.145.200 & Rp 3.200 & 4107,875 \\
\hline Rp 13.145.200 & Rp 3.100 & 4240,387 \\
\hline Rp 13.675.248 & Rp 3.225 & 4240,387 \\
\hline Rp 13.675.248 & Rp 2.900 & 4715,603 \\
\hline Rp 14.854.149 & Rp 3.150 & 4715,603 \\
\hline
\end{tabular}

\begin{tabular}{|l|l|r|}
\hline \multicolumn{4}{|c|}{2006} \\
\hline Rp 10.229.386 & Rp 1.700 & 6017,286 \\
\hline Rp 11.059.772 & Rp 1.838 & 6017,286 \\
\hline Rp 11.059.772 & Rp 1.750 & 6319,87 \\
\hline Rp 11.457.923 & Rp 1.813 & 6319,87 \\
\hline Rp 11.457.923 & Rp 1.775 & 6455,168 \\
\hline Rp 11.619.303 & Rp 1.800 & 6455,168 \\
\hline Rp 11.619.303 & Rp 1.913 & 6073,864 \\
\hline Rp 11.771.149 & Rp 1.938 & 6073,864 \\
\hline Rp 11.771.149 & Rp 1.988 & 5921,101 \\
\hline Rp 11.919.177 & Rp 2.013 & 5921,101 \\
\hline Rp 11.919.177 & Rp 1.975 & 6035,026 \\
\hline
\end{tabular}




\begin{tabular}{|l|l|r|} 
Rp 14.854.149 & Rp 3.000 & 4951,383 \\
\hline Rp 15.596.857 & Rp 3.150 & 4951,383 \\
\hline Rp 15.596.857 & Rp 3.125 & 4990,994 \\
\hline Rp 15.846.406 & Rp 3.175 & 4990,994 \\
\hline Rp 15.846.406 & Rp 3.125 & 5070,85 \\
\hline Rp 16.480.263 & Rp 3.250 & 5070,85 \\
\hline Rp 16.480.263 & Rp 3.025 & 5448,021 \\
\hline Rp 17.706.067 & Rp 3.250 & 5448,021 \\
\hline Rp 17.706.067 & Rp 3.150 & 5620,974 \\
\hline Rp 17.987.116 & Rp 3.200 & 5620,974 \\
\hline Rp 17.987.116 & Rp 3.175 & 5665,233 \\
\hline Rp 18.412.008 & Rp 3.250 & 5665,233 \\
\hline
\end{tabular}

\begin{tabular}{|l|l|l|} 
Rp 12.220.928 & Rp 2.025 & 6035,026 \\
\hline
\end{tabular}

\begin{tabular}{|l|c|c|}
\hline \multicolumn{3}{|c|}{2009} \\
\hline Rp 18.412.008 & Rp 3.500 & 5260,574 \\
\hline Rp 19.595.638 & Rp 3.725 & 5260,574 \\
\hline Rp 19.595.638 & Rp 3.575 & 5481,297 \\
\hline Rp 20.006.735 & Rp 3.650 & 5481,297 \\
\hline Rp 20.006.735 & Rp 3.575 & 5596,289 \\
\hline Rp 20.426.457 & Rp 3.650 & 5596,289 \\
\hline Rp 20.426.457 & Rp 3.550 & 5753,931 \\
\hline Rp 21.433.394 & Rp 3.725 & 5753,931 \\
\hline Rp 21.433.394 & Rp 3.625 & 5912,661 \\
\hline Rp 22.024.661 & Rp 3.725 & 5912,661 \\
\hline Rp 22.024.661 & Rp 3.600 & 6117,961 \\
\hline Rp 22.636.457 & Rp 3.700 & 6117,961 \\
\hline
\end{tabular}

\section{BBCA}

\section{PEDMA}

\begin{tabular}{|c|c|c|}
\hline \multicolumn{3}{|c|}{2006} \\
\hline Rp 10.000 .000 & Rp 1.738 & 5753,74 \\
\hline Rp 10.575.374 & Rp 1.838 & 5753,74 \\
\hline Rp 10.575.374 & Rp 1.750 & 6043,071 \\
\hline Rp 10.956.087 & Rp 1.813 & 6043,071 \\
\hline Rp 10.956.087 & Rp 1.775 & 6172,444 \\
\hline Rp 11.110.399 & Rp 1.800 & 6172,444 \\
\hline Rp 11.110.399 & Rp 1.913 & 5807,84 \\
\hline Rp 11.255.595 & Rp 1.938 & 5807,84 \\
\hline Rp 11.255.595 & Rp 1.988 & 5661,768 \\
\hline Rp 11.397.139 & Rp 2.013 & 5661,768 \\
\hline Rp 11.397.139 & Rp 1.975 & 5770,703 \\
\hline Rp 11.685.674 & Rp 2.025 & 5770,703 \\
\hline
\end{tabular}

24)

Alvin, A. \& Triasurya, D. / Journal of Applied Finance and Accounting 3(1) 1-34 


\begin{tabular}{|c|c|c|}
\hline \multicolumn{3}{|c|}{2008} \\
\hline Rp 11.685 .674 & Rp 3.175 & 3680,527 \\
\hline Rp 11.961.713 & Rp 3.250 & 3680,527 \\
\hline Rp 11.961 .713 & Rp 3.175 & 3767,469 \\
\hline Rp 12.244.274 & Rp 3.250 & 3767,469 \\
\hline Rp 12.244.274 & Rp 3.150 & 3887,071 \\
\hline Rp 12.438.627 & Rp 3.200 & 3887,071 \\
\hline Rp 12.438.627 & Rp 3.175 & 3917,678 \\
\hline Rp 11.948.917 & Rp 3.050 & 3917,678 \\
\hline Rp 11.948.917 & Rp 3.175 & 3763,439 \\
\hline Rp 11.478.488 & Rp 3.050 & 3763,439 \\
\hline Rp 11.478.488 & Rp 2.975 & 3858,315 \\
\hline Rp 11.285.572 & Rp 2.925 & 3858,315 \\
\hline Rp 11.285 .572 & Rp 2.975 & 3793,47 \\
\hline Rp 10.526.878 & Rp 2.775 & 3793,47 \\
\hline Rp 10.526.878 & Rp 3.150 & 3341,866 \\
\hline Rp 10.861.065 & Rp 3.250 & 3341,866 \\
\hline
\end{tabular}

\begin{tabular}{|c|c|c|}
\hline \multicolumn{3}{|c|}{2009} \\
\hline Rp 10.861.065 & Rp 3.500 & 3103,161 \\
\hline Rp 8.611 .273 & Rp 2.775 & 3103,161 \\
\hline Rp 8.611 .273 & Rp 2.975 & 2894,545 \\
\hline Rp $\quad 7.960 .000$ & Rp 2.750 & 2894,545 \\
\hline Rp $\quad 7.960 .000$ & Rp 2.825 & 2817,699 \\
\hline Rp 7.889 .557 & Rp 2.800 & 2817,699 \\
\hline Rp $\quad 7.889 .557$ & Rp 2.925 & 2697,285 \\
\hline Rp 10.047.385 & Rp 3.725 & 2697,285 \\
\hline Rp 10.047.385 & Rp 3.575 & 2810,457 \\
\hline Rp 10.258.169 & Rp 3.650 & 2810,457 \\
\hline Rp 10.258.169 & Rp 3.575 & 2869,418 \\
\hline Rp 10.473.376 & Rp 3.650 & 2869,418 \\
\hline Rp 10.473.376 & Rp 3.550 & 2950,247 \\
\hline Rp 10.989.669 & Rp 3.725 & 2950,247 \\
\hline Rp 10.989.669 & Rp 3.625 & 3031,633 \\
\hline Rp 11.292.832 & Rp 3.725 & 3031,633 \\
\hline Rp 11.292.832 & Rp 3.600 & 3136,898 \\
\hline Rp 11.606.522 & Rp 3.700 & 3136,898 \\
\hline
\end{tabular}

\section{BUMI}

PE

\begin{tabular}{|ll|ll|l|}
\hline \multicolumn{5}{|c|}{2005} \\
\hline Rp & 10.000 .000 & Rp & 780 & 12820,51 \\
\hline Rp & 9.743 .590 & Rp & 760 & 12820,51 \\
\hline
\end{tabular}

\begin{tabular}{|ll|ll|l|}
\hline \multicolumn{5}{|c|}{2006} \\
\hline $\mathrm{Rp}$ & 9.743 .590 & $\mathrm{Rp}$ & 760 & 12820,51 \\
\hline $\mathrm{Rp}$ & 9.743 .590 & $\mathrm{Rp}$ & 760 & 12820,51 \\
\hline $\mathrm{Rp}$ & 9.743 .590 & $\mathrm{Rp}$ & 740 & 13167,01 \\
\hline $\mathrm{Rp}$ & 10.138 .600 & $\mathrm{Rp}$ & 770 & 13167,01 \\
\hline $\mathrm{Rp}$ & 10.138 .600 & $\mathrm{Rp}$ & 760 & 13340,26 \\
\hline $\mathrm{Rp}$ & 10.272 .003 & $\mathrm{Rp}$ & 770 & 13340,26 \\
\hline $\mathrm{Rp}$ & 10.272 .003 & $\mathrm{Rp}$ & 760 & 13515,79 \\
\hline $\mathrm{Rp}$ & 10.407 .161 & $\mathrm{Rp}$ & 770 & 13515,79 \\
\hline
\end{tabular}

\begin{tabular}{|l|r|r|}
\hline \multicolumn{4}{|c|}{2007} \\
\hline Rp 10.407.161 & Rp 910 & 11436,44 \\
\hline Rp 19.441.949 & Rp 1.700 & 11436,44 \\
\hline Rp 19.441.949 & Rp 1.590 & 12227,64 \\
\hline Rp 20.786.989 & Rp 1.700 & 12227,64 \\
\hline Rp 20.786.989 & Rp 2.275 & 9137,138 \\
\hline Rp 37.462.266 & Rp 4.100 & 9137,138 \\
\hline
\end{tabular}

2008 


\begin{tabular}{|l|lr|r|}
\hline \multicolumn{4}{|c|}{2009} \\
\hline Rp 12.849.057 & Rp & 940 & 13669,21 \\
\hline Rp 44.083.200 & Rp 3.225 & 13669,21 \\
\hline
\end{tabular}

\begin{tabular}{|l|l|l|} 
Rp 37.462.266 & Rp 3.275 & 11438,86 \\
\hline Rp 45.183.496 & Rp 3.950 & 11438,86 \\
\hline Rp 45.183.496 & Rp 3.200 & 14119,84 \\
\hline Rp 12.849.057 & Rp 910 & 14119,84 \\
\hline
\end{tabular}

\section{PEDMA}

\begin{tabular}{|ll|ll|l|}
\hline \multicolumn{5}{|c|}{2005} \\
\hline $\mathrm{Rp}$ & 10.000 .000 & $\mathrm{Rp}$ & 780 & 12820,51 \\
\hline $\mathrm{Rp}$ & 9.358 .974 & $\mathrm{Rp}$ & 730 & 12820,51 \\
\hline $\mathrm{Rp}$ & 9.358 .974 & $\mathrm{Rp}$ & 780 & 11998,69 \\
\hline $\mathrm{Rp}$ & 9.119 .001 & $\mathrm{Rp}$ & 760 & 11998,69 \\
\hline $\mathrm{Rp}$ & 9.119 .001 & $\mathrm{Rp}$ & 770 & 11842,86 \\
\hline $\mathrm{Rp}$ & 9.000 .572 & $\mathrm{Rp}$ & 760 & 11842,86 \\
\hline $\mathrm{Rp}$ & 9.000 .572 & $\mathrm{Rp}$ & 780 & 11539,19 \\
\hline $\mathrm{Rp}$ & 9.462 .140 & $\mathrm{Rp}$ & 820 & 11539,19 \\
\hline $\mathrm{Rp}$ & 9.462 .140 & $\mathrm{Rp}$ & 830 & 11400,17 \\
\hline $\mathrm{Rp}$ & 9.348 .138 & $\mathrm{Rp}$ & 820 & 11400,17 \\
\hline $\mathrm{Rp}$ & 9.348 .138 & $\mathrm{Rp}$ & 830 & 11262,82 \\
\hline $\mathrm{Rp}$ & 9.235 .510 & $\mathrm{Rp}$ & 820 & 11262,82 \\
\hline $\mathrm{Rp}$ & 9.235 .510 & $\mathrm{Rp}$ & 840 & 10994,65 \\
\hline $\mathrm{Rp}$ & 9.015 .617 & $\mathrm{Rp}$ & 820 & 10994,65 \\
\hline $\mathrm{Rp}$ & 9.015 .617 & $\mathrm{Rp}$ & 830 & 10862,19 \\
\hline $\mathrm{Rp}$ & 9.015 .617 & $\mathrm{Rp}$ & 830 & 10862,19 \\
\hline $\mathrm{Rp}$ & 9.015 .617 & $\mathrm{Rp}$ & 850 & 10606,61 \\
\hline $\mathrm{Rp}$ & 8.803 .485 & $\mathrm{Rp}$ & 830 & 10606,61 \\
\hline $\mathrm{Rp}$ & 8.803 .485 & $\mathrm{Rp}$ & 850 & 10357,04 \\
\hline $\mathrm{Rp}$ & 8.492 .774 & $\mathrm{Rp}$ & 820 & 10357,04 \\
\hline
\end{tabular}

\begin{tabular}{|rr|rr|r|}
\hline \multicolumn{5}{|c|}{2007} \\
\hline Rp & 8.492 .774 & Rp 910 & 9332,718 \\
\hline Rp 15.865.621 & Rp 1.700 & 9332,718 \\
\hline Rp 15.865.621 & Rp 1.590 & 9978,378 \\
\hline Rp 16.963 .242 & Rp 1.700 & 9978,378 \\
\hline Rp 16.963 .242 & Rp 2.275 & 7456,37 \\
\hline Rp & 30.571 .118 & Rp 4.100 & 7456,37 \\
\hline
\end{tabular}

\begin{tabular}{|l|l|l|}
\hline \multicolumn{4}{|c|}{2009} \\
\hline Rp 30.571.118 & Rp 2.250 & 13587,16 \\
\hline Rp 28.533.044 & Rp 2.100 & 13587,16 \\
\hline Rp 28.533.044 & Rp 1.900 & 15017,39 \\
\hline Rp 48.431.087 & Rp 3.225 & 15017,39 \\
\hline
\end{tabular}

\section{B. Buy and Hold}

\begin{tabular}{|c|r|}
\hline \multicolumn{2}{|c|}{ AALI } \\
\hline \multicolumn{1}{|c|}{ Date } & \multicolumn{1}{c|}{ Price } \\
\hline $03 / 01 / 2005$ & 3075 \\
\hline $29 / 12 / 2005$ & 4900 \\
\hline $02 / 01 / 2006$ & 5050 \\
\hline $28 / 12 / 2006$ & 12600 \\
\hline $02 / 01 / 2007$ & 12800 \\
\hline $28 / 12 / 2007$ & 28000 \\
\hline $02 / 01 / 2008$ & 28350 \\
\hline
\end{tabular}

\begin{tabular}{|c|c|}
\hline \multicolumn{2}{|c|}{ ASII } \\
\hline \multicolumn{1}{|l|}{ Date } & Price \\
\hline $03 / 01 / 2005$ & 9600 \\
\hline $29 / 12 / 2005$ & 10200 \\
\hline $02 / 01 / 2006$ & 10100 \\
\hline $28 / 12 / 2006$ & 15700 \\
\hline $02 / 01 / 2007$ & 16350 \\
\hline $28 / 12 / 2007$ & 27300 \\
\hline $02 / 01 / 2008$ & 26600 \\
\hline
\end{tabular}

\begin{tabular}{|r|r|}
\hline \multicolumn{2}{|c|}{ ANTM } \\
Date & Price \\
\hline $03 / 01 / 2005$ & 346 \\
\hline $29 / 12 / 2005$ & 715 \\
\hline $02 / 01 / 2006$ & 720 \\
\hline $28 / 12 / 2006$ & 1600 \\
\hline $02 / 01 / 2007$ & 1620 \\
\hline $28 / 12 / 2007$ & 4475 \\
\hline $02 / 01 / 2008$ & 4425 \\
\hline
\end{tabular}

26)

Alvin, A. \& Triasurya, D. / Journal of Applied Finance and Accounting 3(1) 1-34 


\begin{tabular}{|r|r|}
\hline $30 / 12 / 2008$ & 9800 \\
\hline $05 / 01 / 2009$ & 11750 \\
\hline $30 / 12 / 2009$ & 22750 \\
\hline
\end{tabular}$\quad$\begin{tabular}{r|r|}
$30 / 12 / 2008$ & 10550 \\
\hline $05 / 01 / 2009$ & 12200 \\
\hline $30 / 12 / 2009$ & 34700 \\
\hline
\end{tabular}$\quad$\begin{tabular}{rr|r|}
$30 / 12 / 2008$ & 1090 \\
\hline $05 / 01 / 2009$ & 1230 \\
\hline $30 / 12 / 2009$ & 2200 \\
\hline
\end{tabular}

\begin{tabular}{|r|r|}
\hline \multicolumn{2}{|c|}{ BBCA } \\
Date & Price \\
\hline $03 / 01 / 2005$ & 1475 \\
\hline $29 / 12 / 2005$ & 1700 \\
\hline $02 / 01 / 2006$ & 1700 \\
\hline $28 / 12 / 2006$ & 2600 \\
\hline $02 / 01 / 2007$ & 2625 \\
\hline $28 / 12 / 2007$ & 3650 \\
\hline $02 / 01 / 2008$ & 3625 \\
\hline $30 / 12 / 2008$ & 3250 \\
\hline $05 / 01 / 2009$ & 3500 \\
\hline $30 / 12 / 2009$ & 4850 \\
\hline
\end{tabular}

\begin{tabular}{|r|r|}
\hline \multicolumn{2}{|c|}{ BUMI } \\
Date & Price \\
\hline $03 / 01 / 2005$ & 780 \\
\hline $29 / 12 / 2005$ & 760 \\
\hline $02 / 01 / 2006$ & 760 \\
\hline $28 / 12 / 2006$ & 900 \\
\hline $02 / 01 / 2007$ & 910 \\
\hline $28 / 12 / 2007$ & 6000 \\
\hline $02 / 01 / 2008$ & 6000 \\
\hline $30 / 12 / 2008$ & 910 \\
\hline $05 / 01 / 2009$ & 940 \\
\hline $30 / 12 / 2009$ & 2425 \\
\hline
\end{tabular}




\section{Paired-Samples t Test}

PE

2005

t-Test: Paired Two Sample for Means

\begin{tabular}{lrr}
\hline & Variable & Variable \\
& \multicolumn{1}{c}{1} & \multicolumn{1}{c}{2} \\
\hline Mean & 0,180174 & 0,13697 \\
Variance & 0,050512 & 0,116401 \\
Observations & 28 & 28 \\
Pearson Correlation & 0,555482 & \\
Hypothesized Mean Difference & 0 & \\
df & 27 & \\
t Stat & 0,799688 & \\
$\mathrm{P}(\mathrm{T}<=\mathrm{t})$ one-tail & 0,215436 & \\
$\mathrm{t}$ Critical one-tail & 1,703288 & \\
$\mathrm{P}(\mathrm{T}<=\mathrm{t})$ two-tail & 0,430872 & \\
$\mathrm{t}$ Critical two-tail & 2,05183 & \\
\hline
\end{tabular}

2006

t-Test: Paired Two Sample for Means

\begin{tabular}{lrr}
\hline & Variable & Variable \\
& 1 & 2 \\
\hline Mean & 0,232273 & 0,700478 \\
Variance & 0,145599 & 0,215067 \\
Observations & 28 & 28 \\
Pearson Correlation & 0,166345 & \\
Hypothesized Mean Difference & 0 & \\
df & 27 & \\
t Stat & $-4,50982$ & \\
P(T<=t) one-tail & $5,68 \mathrm{E}-05$ & \\
t Critical one-tail & 1,703288 & \\
P(T<=t) two-tail & 0,000114 & \\
t Critical two-tail & 2,05183 & \\
\hline
\end{tabular}

28)

Alvin, A. \& Triasurya, D. / Journal of Applied Finance and Accounting 3(1) 1-34 
2007

t-Test: Paired Two Sample for Means

\begin{tabular}{lrr}
\hline & Variable & Variable \\
& 1 & 2 \\
\hline Mean & 0,402126 & 0,718141 \\
Variance & 0,392266 & 1,666517 \\
Observations & 28 & 28 \\
Pearson Correlation & 0,931716 & \\
Hypothesized Mean Difference & 0 & \\
df & 27 & \\
t Stat & $-2,2504$ & \\
P(T<=t) one-tail & 0,016387 & \\
t Critical one-tail & 1,703288 & \\
P(T $<=$ t) two-tail & 0,032774 & \\
t Critical two-tail & 2,05183 & \\
\hline
\end{tabular}

2008

t-Test: Paired Two Sample for Means

\begin{tabular}{lrr}
\hline & Variable & Variable \\
& \multicolumn{1}{c}{1} & \multicolumn{1}{c}{2} \\
\hline Mean & $-0,236$ & $-0,49241$ \\
Variance & 0,138044 & 0,080772 \\
Observations & 28 & 28 \\
Pearson Correlation & 0,664658 & \\
Hypothesized Mean Difference & 0 & \\
df & 27 & \\
t Stat & 4,8443 & \\
P(T<=t) one-tail & $2,31 \mathrm{E}-05$ & \\
t Critical one-tail & 1,703288 & \\
P(T $<=$ t) two-tail & $4,63 \mathrm{E}-05$ & \\
t Critical two-tail & 2,05183 & \\
\hline
\end{tabular}


2009

t-Test: Paired Two Sample for Means

\begin{tabular}{lrr}
\hline & Variable & Variable \\
& 1 & 2 \\
\hline Mean & 0,438391 & 1,134306 \\
Variance & 0,33016 & 1,123116 \\
Observations & 28 & 28 \\
Pearson Correlation & 0,511759 & \\
Hypothesized Mean Difference & 0 & \\
df & 27 & \\
t Stat & $-4,04196$ & \\
$\mathrm{P}(\mathrm{T}<=\mathrm{t})$ one-tail & 0,000198 & \\
t Critical one-tail & 1,703288 & \\
$\mathrm{P}(\mathrm{T}<=\mathrm{t})$ two-tail & 0,000396 & \\
$\mathrm{t}$ Critical two-tail & 2,05183 & \\
\hline
\end{tabular}

30)

Alvin, A. \& Triasurya, D. / Journal of Applied Finance and Accounting 3(1) 1-34 


\section{PEDMA vs B\&H}

\section{5}

t-Test: Paired Two Sample for Means

\begin{tabular}{lrr}
\hline & Variable & Variable \\
& \multicolumn{1}{c}{1} & \multicolumn{1}{c}{2} \\
\hline Mean & 0,075634 & 0,13697 \\
Variance & 0,026459 & 0,116401 \\
Observations & 28 & 28 \\
Pearson Correlation & 0,6972 & \\
Hypothesized Mean Difference & 0 & \\
df & 27 & \\
t Stat & $-1,2684$ & \\
P(T $<=$ t) one-tail & 0,107742 & \\
t Critical one-tail & 1,703288 & \\
P(T $<=t)$ two-tail & 0,215483 & \\
$\mathrm{t}$ Critical two-tail & 2,05183 & \\
\hline
\end{tabular}

2006

t-Test: Paired Two Sample for Means

\begin{tabular}{lrr}
\hline & Variable & Variable \\
& 1 & 2 \\
\hline Mean & 0,117227 & 0,700478 \\
Variance & 0,074819 & 0,215067 \\
Observations & 28 & 28 \\
Pearson Correlation & 0,14268 & \\
Hypothesized Mean Difference & 0 & \\
df & 27 & \\
t Stat & $-6,12752$ & \\
P(T $<=$ t) one-tail & $7,56 \mathrm{E}-07$ & \\
t Critical one-tail & 1,703288 & \\
P(T<=t) two-tail & $1,51 \mathrm{E}-06$ & \\
t Critical two-tail & 2,05183 & \\
\hline
\end{tabular}


2007

t-Test: Paired Two Sample for Means

\begin{tabular}{lrr}
\hline & Variable 1 & Variable 2 \\
\hline Mean & 0,285995 & 0,718141 \\
Variance & 0,351273 & 1,666517 \\
Observations & 28 & 28 \\
Pearson Correlation & 0,938107 & \\
Hypothesized Mean Difference & 0 & \\
df & 27 & \\
t Stat & $-2,99673$ & \\
P(T<=t) one-tail & 0,002896 & \\
t Critical one-tail & 1,703288 & \\
P(T<=t) two-tail & 0,005792 & \\
t Critical two-tail & 2,05183 & \\
\hline
\end{tabular}

\section{8}

t-Test: Paired Two Sample for Means

\begin{tabular}{lrr}
\hline & Variable & Variable \\
\hline Mean & 1 & \multicolumn{1}{c}{2} \\
Variance & $-0,04912$ & $-0,49241$ \\
Observations & 0,012038 & 0,080772 \\
Pearson Correlation & 28 & 28 \\
Hypothesized Mean Difference & $-0,13435$ & \\
df & 0 & \\
t Stat & 27 & \\
$\mathrm{P}(\mathrm{T}<=\mathrm{t})$ one-tail & 7,374035 & \\
t Critical one-tail & $3,11 \mathrm{E}-08$ & \\
$\mathrm{P}(\mathrm{T}<=\mathrm{t})$ two-tail & 1,703288 & \\
$\mathrm{t}$ Critical two-tail & $6,23 \mathrm{E}-08$ & \\
\hline
\end{tabular}

32)

Alvin, A. \& Triasurya, D. / Journal of Applied Finance and Accounting 3(1) 1-34 
2009

t-Test: Paired Two Sample for Means

\begin{tabular}{lrr}
\hline & Variable 1 & Variable 2 \\
\hline Mean & 0,112474 & 1,134306 \\
Variance & 0,046795 & 1,123116 \\
Observations & 28 & 28 \\
Pearson Correlation & 0,61835 & \\
Hypothesized Mean Difference & 0 & \\
df & 27 & \\
t Stat & $-5,74308$ & \\
$\mathrm{P}(\mathrm{T}<=\mathrm{t})$ one-tail & $2,09 \mathrm{E}-06$ & \\
$\mathrm{t}$ Critical one-tail & 1,703288 & \\
$\mathrm{P}(\mathrm{T}<=\mathrm{t})$ two-tail & $4,17 \mathrm{E}-06$ & \\
$\mathrm{t}$ Critical two-tail & 2,05183 & \\
\hline
\end{tabular}

D. SAMPLES

\begin{tabular}{|r|l|}
\hline \multicolumn{2}{|c|}{ List of Samples } \\
\hline 1 & AALI \\
\hline 2 & ASII \\
\hline 3 & ANTM \\
\hline 4 & BBCA \\
\hline 5 & BBNI \\
\hline 6 & BDMN \\
\hline 7 & BLTA \\
\hline 8 & BUMI \\
\hline 9 & GGRM \\
\hline 10 & INCO \\
\hline 11 & INDF \\
\hline 12 & INTP \\
\hline 13 & ISAT \\
\hline 14 & KLBF \\
\hline 15 & MEDC \\
\hline
\end{tabular}




\begin{tabular}{|r|l|}
16 & SMGR \\
\hline 17 & TINS \\
\hline 18 & TLKM \\
\hline 19 & UNTR \\
\hline 20 & UNVR \\
\hline 21 & RALS \\
\hline 22 & MYOR \\
\hline 23 & SMRA \\
\hline 24 & CTRS \\
\hline 5 & CMNP \\
\hline 26 & PNBN \\
\hline 27 & BNII \\
\hline 28 & BNGA \\
\hline
\end{tabular}

